\title{
Perbedaan Kualitas Hidup Antara Wanita Menopause Yang Masih Bersuami Dan Janda Di Kelurahan Banyuanyar, Surakarta
}

\author{
Rini Setyowati \\ Program Studi Psikologi Fakultas Kedokteran, Universitas Sebalas Maret \\ rini.setyowati87@gmail.com \\ Tara Kartika Sunarto \\ Program Studi Psikologi Fakultas Kedokteran, Universitas Sebalas Maret \\ tarakartika95@gmail.com \\ Suci Murti Karini \\ Program Studi Psikologi Fakultas Kedokteran, Universitas Sebalas Maret \\ sucimurtikarini@gmail.com
}

\begin{abstract}
Abstrak
Menopause merupakan fase alami bagi wanita. Berbagai perubahan yang terjadi pada fase ini dapat mempengaruhi kualitas hidup wanita menopause. Perbedaan status perkawinan menjadi salah satu faktor penting yang berpengaruh pada kualitas hidup tersebut. Tujuan penelitian ini adalah untuk mengetahui apakah terdapat perbedaan kualitas hidup antara wanita menopause yang bersuami dan janda di Kelurahan Banyuanyar, Surakarta. Populasi penelitian ini adalah wanita yang mengalami menopause alami minimal 1 tahun, tinggal di Kelurahan Banyuanyar, Surakarta dan berusia 50-65 tahun baik yang masih bersuami maupun yang janda. Teknik pengambilan sampel menggunakan purposive sampling. Sampel yang digunakan berjumlah 60 orang yang terdiri dari 30 wanita menopause yang bersuami dan 30 wanita menopause yang janda. Pengumpulan data menggunakan skala kualitas hidup $(\mathrm{r}=0,865)$ dan data diri responden.

Hasil analisis data menggunakan uji independent sample t-test menunjukkan bahwa tidak terdapat perbedaan kualitas hidup yang signifikan antara wanita menopause yang bersuami dan janda ( $t_{\text {hitung }}=-0,203<t_{\text {tabel }}=2,002, p>0,05$ ). Hasil yang tidak signifikan ini diakibatkan adanya kovariat lain yang memengaruhi variabel kualitas hidup, seperti : status bekerja, pendidikan, usia, jumlah tanggungan anak dan lamanya menopause. Simpulan penelitian ini adalah tidak terdapat perbedaan kualitas hidup yang signifikan antara wanita menopause yang masih bersuami dan janda di Kelurahan Banyuanyar, Surakarta.
\end{abstract}

Kata kunci: kualitas hidup., menopause., janda., bersuami 


\section{Pendahuluan}

Menopause adalah suatu waktu di usia paruh baya, biasanya di akhir empat puluhan atau awal lima puluhan, ketika menstruasi wanita sepenuhnya berakhir (Santrock, 2011). Berbagai perubahan yang terjadi pada fase ini dapat mempengaruhi kualitas hidup wanita menopause. Kualitas hidup merujuk pada keseluruhan rasa kesejahteraan dan kepuasan diri individu tanpa melihat ada tidaknya gejala. Kualitas hidup menentukan apa yang dirasakan wanita perimenopause atau postmenopause secara umum dan khususnya, berkenaan dengan minat hidup, kemampuan untuk menyelesaikan pekerjaan sehari-hari dengan puas, pemeliharaan hubungan interpersonal yang baik, seksualitas, dan merasa sehat secara umum (Utian, 2007).

Penelitian yang membahas perbedaan kualitas wanita menopause yang masih memiliki suami dan yang sudah menjanda dilakukan oleh Mirhaghjou, Niknami, Moridi, Pakseresht dan Kazemnejad (2016) pada 675 wanita menopause di Iran. Hasil penelitian menunjukkan hasil bahwa wanita menopause yang menikah memiliki kualitas hidup yang lebih baik dibandingkan dengan wanita menopause yang janda. Hal ini karena dukungan mental dari suaminya berdampak pada tingginya kualitas hidup wanita menopause yang menikah.

Penelitian sebelumnya yang dilakukan oleh Giannouli dkk., (2012) mengenai kualitas hidup yang diteliti pada 1140 wanita usia madya di Yunani menunjukkan bahwa status pernikahan berhubungan secara signifikan dengan kualitas hidup pada wanita usia madya. Rata-rata kualitas hidup pada wanita yang menikah lebih tinggi dibandingkan dengan wanita yang janda. Hal ini terjadi karena mereka telah kehilangan suami yang dapat membantu mereka dalam menjalani kehidupannya.

Berbeda dengan hasil penelitian tersebut, penelitian dari Putri, Wati dan Ariyantopada (2014) pada 128 wanita menopause yang berusia 45-59 tahun di Puskesmas Sumbersari, Kabupaten Jember menunjukkan secara keseluruhan kualitas hidup wanita menopause tidak berhubungan dengan status perkawinan. Meskipun begitu, penelitian ini menemukan adanya perbedaan secara signifikan 
pada domain fisik dan sosial wanita yang masih memiliki suami bila dibandingkan dengan wanita yang janda.

Peneliti melakukan wawancara dan observasi prapenelitian pada tanggal 22 - 25 Juli 2017 terhadap 4 wanita menopause, yakni 2 wanita menopause yang bersuami dan 2 wanita menopause yang janda di Kelurahan Banyuanyar, Surakarta. Berdasarkan hasil wawancara tersebut, wanita menopause merasa cepat lelah, mudah menangis, sulit untuk berkonsentrasi, mengeluhkan penurunan fisik dan mudah lupa akan sesuatu, tidak memiliki gairah seksual. Hasil observasi menunjukkan bahwa wanita menopause yang janda terlihat tidak mengikuti kegiatan yang diadakan di sekitar lingkungan setelah kematian pasangannya. Hal ini menunjukkan bahwa wanita menopause mengalami penurunan kualitas hidup.

Perbedaan hasil pada penelitian diatas menunjukkan bahwa kualitas hidup pada wanita menopause yang menikah dan yang janda masih menimbulkan sebuah pertanyaan. Berdasarkan penjelasan diatas, maka peneliti bermaksud untuk meneliti perbedaan kualitas hidup antara wanita menopause yang masih bersuami dan janda di Kelurahan Banyuanyar, Surakarta.

\section{Dasar Teori}

1. Menopause

Santrock (2011) menyatakan menopause adalah suatu waktu di usia paruh baya, biasanya di akhir empat puluhan atau awal lima puluhan, ketika menstruasi wanita sepenuhnya berakhir. Diagnosis menopause dibuat setelah terdapat amenorea sekurang-kurangnya satu tahun (Lubis, 2013).

Wanita menopause berdasarkan status perkawinannya dibagi menjadi 2:

a) Wanita menopause yang masih bersuami

Wanita yang mengalami menopause alami, bukan karena histerektomi yang dinyatakan menikah secara sah oleh hukum dan agama yang telah memenuhi syarat-syarat perkawinan berdasarkan undang-undang yang berlaku dan dibuktikan dengan adanya buku nikah yang dikeluarkan oleh pemerintah Indonesia. 
b) Wanita menopause yang janda

Wanita yang mengalami menopause alami, bukan karena histerektomi yang sebelumnya telah menikah namun karena telah bercerai baik karena perceraian hidup maupun meninggalnya pasangan menjadi tidak memiliki suami.

2. Kualitas Hidup Pada Wanita Menopause

Utian (2007) menyatakan kualitas hidup pada wanita menopause merujuk pada keseluruhan rasa kesejahteraan dan kepuasan diri individu tanpa melihat ada tidaknya gejala. Kualitas hidup ini juga menentukan apa yang dirasakan wanita perimenopause atau postmenopause secara umum dan khususnya, berkenaan dengan minat hidup, kemampuan untuk menyelesaikan pekerjaan sehari-hari dengan puas, pemeliharaan hubungan interpersonal yang baik, seksualitas, dan merasa sehat secara umum.

3. Perbedaan Kualitas Hidup antara Wanita Menopause yang Masih Bersuami dan Janda.

Berdasarkan status perkawinannya, wanita menopause terbagi menjadi dua, yaitu: wanita menopause yang masih bersuami dan wanita menopause yang janda. Wanita menopause tentunya memiliki alasan untuk berumah tangga. Beberapa alasan untuk berumah tangga adalah untuk memenuhi kebutuhan fisiologis, psikologis, dan sosial individu (Walgito, 2010). Kebutuhan fisiologis individu adalah kebutuhan seksual. Apabila kebutuhan tersebut tidak terpenuhi, maka individu akan mengalami gangguan pada dirinya. Individu akan berusaha untuk memuaskan hasrat fisiologisnya untuk melakukan hubungan seksual.

Wanita menopause yang memiliki suami bisa memenuhi hasrat fisiologisnya untuk berhubungan seksual. Wanita yang menikah memiliki kepuasaan relasi seksual yang lebih baik dibandingkan yang tidak memiliki suami. Sebanyak 43\% wanita di Amerika yang menikah merasa sangat puas dengan relasi seksualnya (Lestari, 2016). Maka dari itu, kualitas hidup wanita menopause akan lebih baik bila dibandingkan dengan wanita menopause yang tidak memiliki suami. 
Kepuasan seksual sendiri tidak hanya berasal dari hubungan seksual yang dijalaninya. Komunikasi yang intim dengan pasangan tentu akan meningkatkan kualitas hidup wanita menopause. Suami akan lebih mengerti perubahan yang dialami oleh wanita menopause sehingga akan timbul kedekatan yang intim antar keduanya. Kedekatan emosional ini tentunya akan membuat istri merasa dihargai dan dicintai oleh pasangannya. Hal ini sesuai dengan salah satu faktor kualitas hidup yaitu: dukungan dari keluarga yang dapat meningkatkan kualitas hidup wanita menopause (Suardiman, 2011).

Salah satu faktor yang memengaruhi kualitas hidup adalah pendapatan (Suadirman, 2011). Individu yang menikah lebih sejahtera secara ekonomi (Lestari, 2016). Hal ini karena individu yang menikah dapat menggabungkan pendapatannya sehingga dapat meningkatkan kemampuan ekonominya. Lain halnya dengan individu yang kehilangan pasangannya, kesejahteraan individu tersebut tentu lebih rendah dibandingkan dengan yang memiliki pasangan. Hal ini sesuai dengan pernyataan Bennett dan Soulsby (2012) yang menyatakan kehilangan pasangan hidup akan memengaruhi sebagian besar kehidupan dan berpengaruh secara signifikan pada kualitas hidup pasangannya baik pada psikologi, sosial, fisik, praktik dan ekonomi. Penelitian dari Mirhaghjou, Niknami, Moridi, Pakseresht dan Kazemnejad (2016) pada 675 wanita menopause di Iran menunjukkan wanita yang menikah memiliki kualitas hidup yang lebih baik dibandingkan dengan wanita yang janda. Hal ini karena dukungan mental dari suaminya berdampak pada tingginya kualitas hidup wanita yang menikah.

\section{Metode Penelitian}

Populasi dalam penelitian ini adalah wanita yang sudah tidak mengalami menstruasi minimal 1 bulan terakhir, wanita yang mengalami menopause alami, tinggal di Kelurahan Banyuanyar, Surakarta dan berusia 50-65 tahun baik yang masih bersuami maupun yang janda.

Kriteria eksklusi dari populasi adalah wanita yang mengalami menopause akibat pengangkatan rahim (histerektomi) atau yang bukan karena menopause 
alami serta wanita yang menjadi janda akibat perceraian serta wanita menopause yang menjadi tidak memiliki suami karena perceraian.

Sampel diambil dari kriteria inklusi populasi dengan kriteria tambahan sebagai berikut :

a. Wanita menopause yang masih bersuami

Memiliki suami dan bersedia berpartisipasi dalam penelitian dan mengisi lembar informed consent yang diberikan peneliti.

b. Wanita menopause yang janda

Berstatus janda karena meninggalnya pasangan dengan jangka waktu minimal 1 tahun.

Peneliti menggunakan 94 sampel yang terdiri dari 34 sampel untuk uji coba dan 60 sampel penelitian yang masing-masing terbagi menjadi 30 sampel untuk tiap kelompok.

Pengumpulan data menggunakan alat ukur sebagai berikut :

a. Skala Kualitas Hidup

Peneliti menggunakan skala kualitas hidup dari Utian, yaitu: UQOL (Utian Quality of Life Scale) yang telah dimodifikasi oleh peneliti. Skala kualitas hidup terdiri dari 21 aitem. Hasil uji validitas menunjukkan uji daya beda 0,343 hingga 0,680 dan reliabilitas skala 0,865 .

b. Data Diri Responden Penelitian

Data diri responden penelitian yang disusun oleh peneliti dalam penelitian ini berfungsi sebagai data tambahan untuk mengetahui lebih jauh informasi mengenai wanita menopause tersebut. Data ini juga digunakan untuk memilah responden apakah sesuai dengan kriteria wanita menopause yang telah peneliti tentukan.

\section{Hasil Dan Pembahasan}

\section{Hasil Penelitian}

a. Uji Normalitas

Uji normalitas menggunakan uji Kolmogorov Smirnov menunjukkan taraf 
signifikansi sebesar 0,062 dan 0,128 ( $\mathrm{p}>0,05)$ untuk kelompok wanita menopause yang masih bersuami dan janda. Angka tersebut menunjukkan kedua data kelompok tersebut terdistribusi normal.

b. Uji Homogenitas

Uji homogenitas menggunakan uji Levene's Test menunjukkan taraf signifikansi sebesar 0,835 ( $\mathrm{p}>0,05)$. Angka tersebut menunjukkan data tersebut homogen.

Hasil Uji Hipotesis

Hasil uji independent sample t-test menunjukkan bahwa, $\mathrm{t}_{\text {hitung }}=-0,203<$ $t_{\text {tabel }}=2,002, p=0,840>0,05$ sehingga dapat ditarik kesimpulan bahwa tidak ada perbedaan kualitas hidup secara signifikan antara wanita menopause yang masih bersuami dan janda di Kelurahan Banyuanyar, Surakarta.

Hasil Analisis Tambahan

a. Berdasarkan Status Bekerja

Hasil analisis tambahan menggunakan uji ANACOVA diperoleh nilai

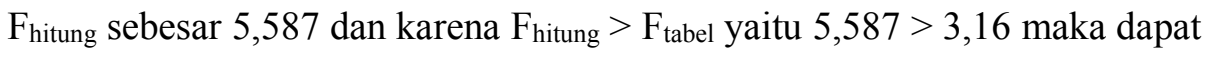
disimpulkan terdapat perbedaan yang signifikan skor rata-rata kualitas hidup wanita menopause berdasarkan status bekerja.

b. Berdasarkan Pendidikan Terakhir

Hasil analisis tambahan menggunakan uji ANACOVA diperoleh nilai

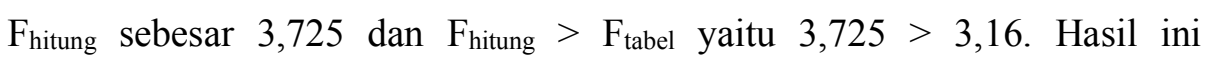
menunjukkan bahwa terdapat perbedaan yang signifikan skor rata-rata kualitas hidup wanita menopause berdasarkan pendidikan.

c. Berdasarkan Usia

Hasil analisis tambahan menggunakan uji ANACOVA diperoleh nilai $F_{\text {hitung }}$ sebesar 8,328 dan karena $F_{\text {hitung }}>F_{\text {tabel yaitu }}$ 8,328 $>3,16$ maka dapat disimpulkan bahwa terdapat perbedaan yang signifikan skor rata-rata kualitas hidup wanita menopause berdasarkan usia.

d. Berdasarkan Pendapatan

Hasil analisis tambahan menggunakan uji ANACOVA diperoleh nilai

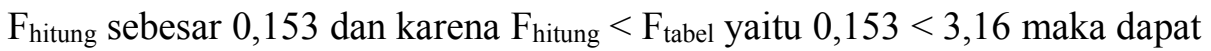


disimpulkan bahwa tidak perbedaan yang signifikan skor rata-rata kualitas hidup wanita menopause berdasarkan pendapatan.

e. Berdasarkan Jumlah Anak yang Ditanggung

Hasil analisis tambahan menggunakan uji ANACOVA diperoleh nilai $F_{\text {hitung }}$ sebesar 3,970 dan karena $F_{\text {hitung }}>F_{\text {tabel }}$ yaitu 3,970 $>$ 3,16 maka dapat disimpulkan bahwa terdapat perbedaan yang signifikan skor rata-rata kualitas hidup wanita menopause berdasarkan anak yang ditanggung.

\section{f. Berdasarkan Lama Menopause}

Hasil analisis tambahan menggunakan uji ANACOVA diperoleh nilai $F_{\text {hitung }}$ sebesar 7,891 dan karena $F_{\text {hitung }}>F_{\text {tabel }}$ yaitu 7,891 $>$ 3,16 maka dapat disimpulkan bahwa terdapat perbedaan yang signifikan skor rata-rata kualitas hidup antara wanita menopause berdasarkan lamanya menopause.

\section{Pembahasan}

Hasil analisis data penelitian mengenai perbedaan kualitas hidup antara wanita menopause yang masih bersuami dan janda di Kelurahan Banyuanyar, Surakarta menunjukkan nilai $t_{\text {hitung }}$ yang diperoleh sebesar - 0,203 dan nilai $t_{\text {tabel }}$ sebesar 2,002 sehingga nilai thitung $-0,203<t_{\text {tabel }}$ 2,002 dan nilai signifikansi ( $p$ value) $0,840>0,05$. Berdasarkan hasil tersebut dapat disimpulkan bahwa hipotesis dalam penelitian ini tidak diterima, yaitu tidak terdapat perbedaan yang signifikan antara kualitas hidup antara wanita menopause yang masih bersuami dan janda di Kelurahan Banyuanyar, Surakarta.

Hasil penelitian ini tidak sejalan dengan penelitian Giannouli dkk., (2012) yang menunjukkan bahwa status pernikahan berhubungan secara signifikan dengan kualitas hidup pada wanita usia madya. Akan tetapi, hasil penelitian ini sejalan dengan penelitian dari $\mathrm{Wu}$, Lai, Hwang (2012) pada 1098 wanita menopause di Taiwan, penelitian dari Putri, Wati dan Ariyantopada (2014) pada 128 wanita menopause di Puskesmas Sumbersari, Kabupaten Jember serta penelitian Shirvani dan Heidari (2016) pada 80 wanita menopause di Iran yang menyatakan kualitas hidup wanita menopause tidak berhubungan dengan status perkawinan.

Hasil yang tidak signifikan ini bisa terjadi karena kurangnya pemahaman 
suami mengenai menopause dan perubahan yang dialami pasangannya. Hal ini perlu disoroti karena saat peneliti melaksanakan penelitian beberapa suami dari wanita menopause tersebut sempat mengeluhkan tidak paham dengan perubahanperubahan yang dialami istrinya setelah menopause. Kurangnya pemahaman ini bisa mengakibatkan konflik interpersonal antara suami-istri khususnya yang terkait dengan masalah seksual. Hal ini dapat dilihat dari rerata skor kualitas hidup secara keseluruhan, yaitu : 61,5333 dan rerata skor dari aspek kualitas hidup seksual wanita menopause yang masih bersuami dengan skor 11,466667 yang lebih rendah dibandingkan wanita menopause yang janda. Rodolpho, Quirino, Hoga, Rosa (2015) menyatakan bahwa pemahaman yang baik mengenai perubahan yang dialami wanita menopause bisa menunjang kualitas hidup wanita menopause sehingga diperlukan pemahaman tentang perubahan menopause dan cara untuk meningkatkan kualitas hidup tersebut.

Hal lain yang perlu dipertimbangkan adalah gaya hidup. Suardiman (2011) menyatakan salah satu faktor yang memengaruhi kualitas hidup wanita menopause adalah gaya hidup. Gaya hidup yang sehat tentu akan membuat kualitas hidup individu lebih baik. Akan tetapi, baik wanita menopause yang masih bersuami maupun yang janda termasuk aktif melakukan olahraga minimal 3 kali seminggu secara berturut-turut berjumlah 19 orang dan 17 orang. Meskipun begitu, jumlah wanita menopause janda yang berolahraga lebih dari 3 kali seminggu sedikit lebih tinggi dari wanita menopause yang masih bersuami. Data ini didapat dari jawaban responden pada aitem 10 pada skala kualitas hidup yang peneliti berikan. Hal ini menunjukkan bahwa secara keseluruhan tidak ada perbedaan yang signifikan antara keduanya. Baik kualitas hidup wanita menopause yang masih bersuami maupun janda sama-sama memiliki kualitas hidup sedang sebanyak $20 \%$ dan hanya berbeda 3,333333\% untuk kategori kualitas hidup sangat tinggi untuk wanita menopause yang janda.

Peneliti menemukan faktor yang memengaruhi kualitas hidup secara signifikan pada wanita menopause adalah status bekerja, pendidikan, usia, jumlah tanggungan anak dan lamanya menopause. Selain itu, penelitian-penelitian yang signifikan mengenai perbedaan kualitas hidup antara wanita menopause yang 
ISSN : $1858-4063$

EISSN : 2503-0949

Vol. 14, No. 2, Oktober 2018

bersuami dan janda juga lebih banyak dilakukan di luar negeri sehingga ada kemungkinan perbedaan budaya dan pandangan hidup yang membuat hasil penelitian tersebut belum bisa diterapkan di Indonesia. 


\section{Kesimpulan dan Saran}

\section{Kesimpulan}

Berdasarkan hasil penelitian yang diperoleh, dapat diambil simpulan bahwa tidak terdapat perbedaan kualitas hidup yang signifikan antara wanita menopause yang menikah dan janda di Kelurahan Banyuanyar, Surakarta. Hasil yang tidak signifikan ini karena peneliti menemukan kovariat lain seperti : status bekerja, pendidikan, usia, jumlah tanggungan anak dan lamanya menopause yang memengaruhi depresi pada wanita menopause yang bersuami dan janda di Kelurahan Banyuanyar.

\section{Saran}

Berdasarkan hasil penelitian, peneliti mengajukan beberapa saran sebagai berikut:

1. Untuk Wanita Menopause

Wanita menopause sebaiknya melakukan kegiatan positif, seperti : melakukan olahraga ringan dan melakukan kegiatan keagamaan untuk mengisi kegiatan sehari-hari. Nantinya, dengan adanya kegiatan ini wanita menopause diharapkan dapat mencapai successful aging dalam menjalani masa tuanya.

2. Untuk Keluarga dan Masyarakat Setempat

Keluarga dan masyarakat disarankan untuk lebih memperhatikan kesejahteraan wanita menopause dengan cara membangun komunikasi antar keluarga dan orang terdekat agar perasaan-perasaan negatif yang dialami oleh wanita menopause bisa tersalurkan dengan positif.

3. Untuk Puskesmas dan lembaga terkait lainnya

Puskesmas sebaiknya membuat pemetaan data jumlah wanita menopause di Kelurahan Banyuanyar, Surakarta. Hal ini bisa bermanfaat untuk mengetahui jumlah wanita menopause dan usia ratarata wanita menopause di Kelurahan Banyuanyar, Surakarta.

4. Untuk Posyandu Lansia maupun PKK (Pembinaan Kesejahteraan Keluarga) 
Posyandu Lansia maupun PKK sebaiknya lebih memperhatikan kesejahteraan anggota-anggotanya serta melakukan kegiatan rekreasi, kegiatan donasi maupun acara berkumpul bersama bisa dijadikan sebagai ajang mempererat kekeluargaan antar anggota sehingga setiap anggota dapat merasakan dukungan sosial dari anggota yang lain.

\section{Peneliti Selanjutnya}

Peneliti dapat melakukan penelitian pada wilayah lebih luas, menggunakan sampel yang lebih banyak, memperbaiki instrumen penelitian dengan menambahkan beberapa faktor prediktor yang dapat memengaruhi variabel kualitas hidup dalam penelitian serta mempersiapkan pelaksanaan penelitian dengan matang.

\section{DAFTAR PUSTAKA}

Bennett, K. M., \& Soulsby, L. K. (2012). Wellbeing in bereavement and widowhood. Illness, Crisis \& Loss, 20(4), 321-337

Giannouli, P., Zervas, I., Armenia, E., Koundi, K., Spyropoulou, A., Alexandrou, A., ...Lambrinoudaki, I. (2012). Determinants of quality of life in Greek middle-age women: A population survey. Maturitas, 71, 154-161

Lestari, S. (2016). Psikologi Keluarga. Jakarta : Prenadamedia Group

Lubis, N. L. (2013). Psikologi Kespro Wanita dan Perkembangan Reproduksinya Ditinjau dari Aspek Fisik dan Psikologis. Medan : Kencana Prenada Media Group

Mirhaghjou, S. N., Niknami, M., Moridi, M., Pakseresht, S., \& Kazemnejad, E. (2016). Quality of life and its determinants in postmenopausal women: a population-based study. Journal Applied Nursing Research, 30, 252-256

Putri, D. I., Wati, D. M., \& Ariyanto, Y. (2014). Kualitas hidup wanita menopause (quality of life among menopausal women). e-Jurnal Pustaka Kesehatan, 2(1), 167-174

Rodolpho, J. R. C., Quirino, B. C., Hoga, L. A. K., \& Rosa, P. L. F. S. (2015). Men's perceptions and attitudes toward their wives experiencing menopause. Journal of Women \& Aging, http://dx.doi.org/10.1080/08952841.2015.1017430

Santrock, J. W. (2011). Life Span Development Perkembangan Masa Hidup (edisi ketigabelas). Alih Bahasa : Benedicte Widyasinta. Jakarta : Erlangga 
ISSN : $1858-4063$

EISSN : 2503-0949

Vol. 14, No. 2, Oktober 2018

Suardiman, S. P. (2011). Psikologi Usia Lanjut. Yogyakarta : Gadjah Mada University Press

Utian, W. H. (2007). Quality of life (QOL) in menopause. Maturitas, 57, 100-102

Utian, W. H., Janata, J. W., Kingsberg, S. A., Schluchter, M., \& Hamilton, J. C. (2002). The Utian Quality of Life (UQOL) Scale: development and validation of an instrument to quantify quality of life through and beyond menopause. Menopause: The Journal of The North American Menopause Society, 9(6), 402-410

Walgito, B. (2010). Bimbingan dan Konseling Perkawinan. Jakarta : Andi Publisher

Wu, Hsien-C., Lai, Jung-N., \& Hwang, Jing-S. (2012). Quality of life and sleep quality amongst climacteric women seeking medical advice in Northern Taiwan. Sleep Medicine, 13, 906912 